\title{
Effect of crocus sativus on gentamicin induced nephrotoxicity
}

\section{MARJAN AJAMI ${ }^{\mathrm{A}}$, SHAHRIAR EGHTESADI ${ }^{\mathrm{A}}$, HAMIDREZA PAZOKI-TOROUDI ${ }^{\mathrm{B}, \mathrm{C}}$, ROUHOLLAH HABIBEY ${ }^{\mathrm{B}}$ and SOLTAN AHMED EBRAHIMI ${ }^{\mathrm{D}}$}

\author{
${ }^{a}$ Department of Nutrition Iran University of Medical Sciences, Tehran, Iran, \\ b Department of Physiology Iran University of Medical Sciences, Tehran, Iran, \\ ${ }^{\mathrm{c}}$ Nano Vichar Pharmaceutical Ltd, Tehran, Iran \\ ${ }^{\mathrm{d}}$ Department of Pharmacology Iran University of Medical Sciences, Tehran, Iran,
}

\begin{abstract}
Crocus sativus, known as saffron, is used in folk medicine for treatment of different types of diseases, and its anti-inflammatory and free radical scavenging activities have been demonstrated. The present study evaluated gentamicin nephrotoxicity in saffron treated rats.

Male Wistar rats (200-250g) were treated with saffron (40 or $80 \mathrm{mg} / \mathrm{k} / \mathrm{d}$ ) for 10 days, or saffron $(40 \mathrm{or} 80 \mathrm{mg}$ / $\mathrm{kg} / \mathrm{d}$ ) for 10 days and gentamicin $80 \mathrm{mg} / \mathrm{kg} / \mathrm{d}$ for five days, starting from day 6 . At the end of treatment, blood samples were taken for measurement of serum creatinine (SCr) and BUN. The left kidney was prepared for histological evaluation and the right kidney for Malondialdehyde (MDA) measurement.

Gentamicin $80(\mathrm{mg} / \mathrm{k} / \mathrm{d})$ increased SCr, BUN and renal tissue levels of MDA and induced severe histological changes. Saffron at $40 \mathrm{mg} / \mathrm{k} / \mathrm{d}$ significantly reduced gentamicin-induced increases in BUN and histological scores $(\mathrm{p}<0.05)$. Gentamicin-induced increases in $\mathrm{BUN}, \mathrm{SCr}$ and MDA and histological injury were significantly reduced by treatment with saffron $80 \mathrm{mg} / \mathrm{k} / \mathrm{d}(\mathrm{p}<0.05, \mathrm{p}<0.001, \mathrm{p}<0.05$, and $\mathrm{p}<0.001$ respectively). In conclusion, our results suggest that saffron treatment reduces gentamicin-induced nephrotoxicity and this effect seems to be dose dependent.
\end{abstract}

Key terms: Saffron, Malondialdehyde (MDA), aminoglycoside, renal failure.

\section{INTRODUCTION}

Aminoglycosides, such as gentamicin, are a class of clinically important antibiotics used extensively in the treatment of infections, particularly against aerobic gram-negative bacteria (Nagai and Takano, 2004). However, nephrotoxicity and ototoxicity there are serious side effects in the use of aminoglycosides. The toxicity of gentamicin, the most widely used drug in this category, is believed to be related to the generation of reactive oxygen species (ROS) in the kidney (Baliga et al., 1999; Martínez-Salgado et al., 2002). ROS induces vasoconstriction and decreases glomerular filtration rate (GFR). ROS also induces cellular injury and necrosis via lipid peroxidation and protein modification (Edson and Terrell, 1999). Most of the intravenously administered dose is excreted in the urine, whereas some of the aminoglycoside injected is selectively accumulated in the renal cortex (Nagai and Takano, 2004; Konopska and Warwas, 2007) leading to renal cell injury.

Crocus sativus L. (Iridaceae), commonly known as saffron, is used in folk medicine for various purposes, such as an aphrodisiac, antispasmodic and for expectorant effects (Rios et al., 1996). Modern pharmacological studies have demonstrated that saffron extracts have antinociceptive, antiinflammatory (Hosseinzadeh and Younesi, 2002), antitumour (Escribano et al., 1996; Nair et al., 1991; Salomi et al., 1991), 
radical scavenger (Abdullaev, 1993), and anticonvulsant effects (Hosseinzadeh and Khosravan, 2002). In addition, it has been shown that saffron improves learning and memory (Abe et al., 1999; Zhang et al., 1994). Chemical studies of $C$. sativus have shown the constituents to include crocin, crocetin, safranal and picrocrocin (Tarantilis et al., 1995; Escribano et al., 1996; Lozano et al., 2000). Among these constituents, crocetin is mainly responsible for pharmacological activities (Abe et al., 1999).

A recent study demonstrated protective effects for aqueous saffron extract (Crocus sativus L.) and its active constituent, crocin, against renal ischemia reperfusion induced oxidative injury in rats (Hosseinzadeh et al., 2005). We then attempted to develop new strategies for preventing the nephrotoxicity of aminoglycosides. The aim of the present study was to assess the protective effects of aqueous saffron extract on gentamicin induced nephrotoxicity in rats.

\section{MATERIALS AND METHODS}

\section{Animals}

The experimental protocol was approved by the Ethics Review Committee for Animal Experimentation of Iran University of Medical Sciences. Adult male wistar rats weighing 200-250 g were used. All of them were kept in the same room under a constant temperature $\left(22 \pm 2{ }^{\circ} \mathrm{C}\right)$ and illuminated 7: 00 a.m. to 7: 00 p.m., with food pellets and water available ad libitum.

\section{Experimental design}

Animals were divided randomly into six groups, each with 8 rats. Group 1 was the control group in which animals were only treated with normal saline for five days, Group 2 was given gentamicin (AlborzDarou Pharmaceutical Co.) $80 \mathrm{mg} / \mathrm{kg} / \mathrm{d}$ (IP) for five days, Group 3 was given aqueous saffron extract $(40 \mathrm{mg} / \mathrm{kg} / \mathrm{d})$ orally for 10 days, Group 4 was given aqueous saffron extract $(80 \mathrm{mg} / \mathrm{kg} / \mathrm{d})$ orally for 10 days, Group 5 was given aqueous saffron extract
(40 mg/kg/d) orally for 10 days and was given $80 \mathrm{mg} / \mathrm{kg} / \mathrm{d}$ gentamicin (IP) for five days starting from day 6 , Group 6 was given aqueous saffron extract $(80 \mathrm{mg} / \mathrm{kg} / \mathrm{d})$ orally for 10 days and was given gentamicin $80 \mathrm{mg} / \mathrm{kg} / \mathrm{d}$ (IP) for five days starting from day 6 .

After 5 days of treatment with gentamicin $(80 \mathrm{mg} / \mathrm{kg} / \mathrm{d})$, control and experimental animals were anaesthetized with Xylazine $(10 \mathrm{mg} / \mathrm{kg} / \mathrm{d})$ and Ketamine $\mathrm{HCl}(50 \mathrm{mg} / \mathrm{kg} / \mathrm{d}) ;$ Xylazine was purchased from Chanelle Pharmaceutical Co., Galway, Ireland and Ketamine $\mathrm{HCl}$ from ParkeDavis Pharmaceutical Co., Cambridge, UK. Then anaesthetized rats were sacrificed in a rapid and painless method and blood was collected and serum samples were separated by centrifugation and used for measurement of serum creatinine ( $\mathrm{SCr}$ ) and BUN using a commercial kit (PA, Tehran, Iran) and Hitachi multianalyser (Hitachinaka, Japan). The abdomen was opened and kidneys were dissected out and the left kidneys were processed for light microscopic (OlympusBH-2) observation, according to standard procedures. The kidneys were fixed in phosphate-buffered $10 \%$ formalin and then embedded in paraffin wax, sectioned (4$5 \mu \mathrm{m})$ and stained with Hematoxylin and Eosin (H\&E). The right kidneys were removed and maintained at $-80{ }^{\circ} \mathrm{C}$ (Fernandez et al., 1997). On the day of analysis, the kidney tissues were homogenized in cold $\mathrm{KCl}$ solution (1.5\%) to give a $10 \%$ homogenate suspension and used for biochemical assays.

\section{MDA measurement}

Malondialdehyde (MDA) levels, as an index of lipid peroxidation, were measured in renal tissue. MDA, as a thiobarbituric acid reactive substance (TBARS), reacts with thiobarbituric acid (TBA) to produce a red colored complex that has peak absorbance at $532 \mathrm{~nm}$ (Fernandez et al., 1997). Absorbance was measured in the visible range using an ELISA plate reader (Helsinki, Finland).

Phosphoric acid $(3 \mathrm{ml} ; 1 \%)$ and TBA (1 $\mathrm{ml} ; 0.6 \%$ ) were added to $0.5 \mathrm{ml}$ of homogenate in a centrifuge tube and the 
mixture was heated for $45 \mathrm{~min}$ in a boiling water bath. After cooling, $4 \mathrm{ml}$ of n-butanol was added to the mixture and vortex-mixed for $1 \mathrm{~min}$ followed by centrifugation at $20000 \mathrm{rpm}$ for $20 \mathrm{~min}$. The organic layer was transferred to a fresh tube and its absorbance was measured at $532 \mathrm{~nm}$. The standard curve of MDA was constructed over the concentration range of $0-40 \mu \mathrm{M}$ (Uchiama and Miahara, 1978).

\section{Determination of renal tissue injury}

The severity of the histological lesion was graded from 0 to 4 , by a blindfold fashion (all slices were evaluated by two blind-folded pathologists and the results were collectively introduced in analysis and explanation), as the following (Jablonski et al., 1983):

0; no sign of necrosis (no damage), 1+; necrosis of individual cells, 2+; necrosis of all cells in adjacent proximal convoluted tubules, with survival of surrounding tubules, 3+; necrosis confined to the distal third of the proximal convoluted tubule with a band of necrosis extending across the inner cortex. 4+; necrosis affecting all the three segments of the proximal convoluted tubule.

\section{Statistical analysis}

Serum Cr and BUN and tissue MDA levels are presented as Means \pm S.E.M. Means of groups were compared by one-way analysis of variance (ANOVA) then Post-Hoc analysis (Tukey test) was performed for assessing specific group comparisons. Mann-Whitney U test was used for comparison of histological data. The level of statistical significance was accepted as $\mathrm{p}$ $<0.05$. Calculations were performed using the SPSS statistical package (version 14).

\section{RESULTS}

\section{Serum Creatinine and BUN}

Serum creatinine $(\mathrm{SCr})$ and $\mathrm{BUN}$ were normal in control group $(0.55 \pm 0.03$ and $17.7 \pm 2.07, \mathrm{n}=8)$. Treatment with gentamicin for five days induced renal functional deficiency as demonstrated by significant increase in $\mathrm{SCr}$ and BUN levels $(1.05 \pm 0.07$ and $49.67 \pm 3.97, \mathrm{p}<0.001$, Figure 1 and 2). Saffron at doses of $40 \mathrm{mg} /$ $\mathrm{k} / \mathrm{d}$ or $80 \mathrm{mg} / \mathrm{k} / \mathrm{d}$ did not significantly change serum creatinine $(0.54 \pm 0.02$ or $0.63 \pm 0.03$, Figure 1) and BUN (17.33 \pm 1.706 or $18.83 \pm 1.95$, Figure 2 ).

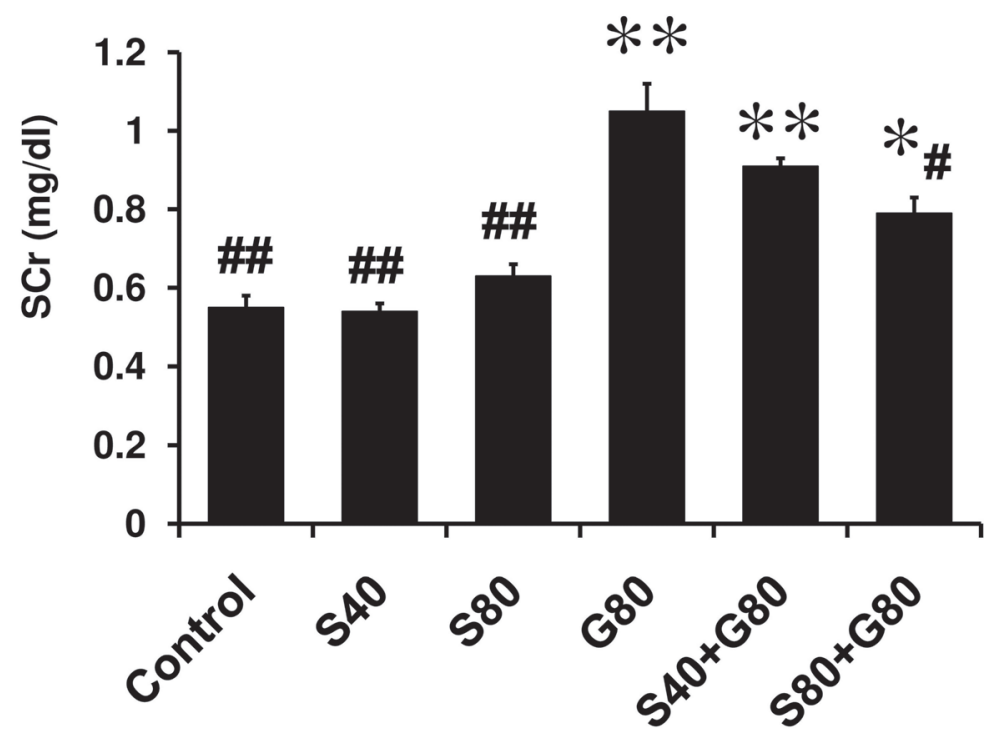

Figure 1: effect of different doses of saffron and gentamicin treatment on serum creatinine Data are expressed as Mean \pm S.E.M for groups of 8 rats each. S40: Saffron $40 \mathrm{mg} / \mathrm{k} / \mathrm{d}, \mathrm{S} 80$ : Saffron $80 \mathrm{mg} / \mathrm{k} / \mathrm{d}, \mathrm{G} 80$ : Gentamicin $80 \mathrm{mg} / \mathrm{k} / \mathrm{d}$. * ${ }^{*}<0.05$ in comparison to the control group, ** $\mathrm{p}<0.01$ vs. control group. \# $\mathrm{p}<0.05$ in comparison to the $\mathrm{G} 80$ treated group, \#\# $\mathrm{p}<0.01$ in comparison to the G80 treated group (One-way ANOVA followed by Post Hoc Tukey test). 
Treatment with saffron $40 \mathrm{mg} / \mathrm{k} / \mathrm{d}$ for five days before gentamicin treatment and five days co-treatment reduced functional defects revealed by significant decreases in serum BUN levels $(30.67 \pm 3.67 \mathrm{p}<0.05$, Figure 2), whereas the effects on $\mathrm{SCr}$ were not statistically significant $(0.91 \pm 0.02$, Figure 1). Moreover, $\mathrm{SCr}$ and $\mathrm{BUN}$ in the $\mathrm{S} 40+\mathrm{G} 80$ treated group showed a significant difference when compared to the control group $(\mathrm{p}<0.01$ and $\mathrm{p}<0.05$, respectively, Figure 1 and 2).

Gentamicin-induced nephrotoxicity was reduced significantly by the saffron $80 \mathrm{mg} /$ $\mathrm{k} / \mathrm{d}$ treatment as shown by decreased levels of SCr and BUN $(0.79 \pm 0.04, \mathrm{p}<0.05$ and $24 \pm 2.91, \mathrm{p}<0.001$ respectively, Figure 1 and 2). In addition, $\mathrm{SCr}$ in this group was significantly higher than in the control group $(\mathrm{p}<0.05$, Figure 1$)$.

\section{Modulation of MDA levels by saffron extract}

Tissue MDA levels increased from $40.7 \pm$ 3.2 in control group to $83.46 \pm 8.11$ in gentamicin $80 \mathrm{mg} / \mathrm{k} / \mathrm{d}$ treated rats $(\mathrm{p}<0.001$, Figure 3). Saffron at $40 \mathrm{mg} / \mathrm{k} / \mathrm{d}$ and $80 \mathrm{mg} /$ $\mathrm{k} / \mathrm{d}$ did not change tissue MDA levels (46.3 \pm 3.46 and $41.25 \pm 4.01$, respectively). Increased tissue levels of MDA in gentamicin $(80 \mathrm{mg} / \mathrm{k} / \mathrm{d})$ treated rats were reduced by pre and co-treatment with saffron $80 \mathrm{mg} / \mathrm{k} / \mathrm{d}(55.9 \pm 6.5, \mathrm{p}<0.05$, Figure 3). In the case of $40 \mathrm{mg} / \mathrm{k} / \mathrm{d}$ saffron, this was not significant $(77.51 \pm 6.76)$.

\section{Histological evaluation}

In the control group, saline treatment failed to produce histological lesions in the left kidneys. Treatment with gentamicin $80 \mathrm{mg} /$ $\mathrm{k} / \mathrm{d}$ for five days induced moderate to severe histological damage $(\mathrm{p}<0.001$, Table 1) with dominant tubular necrosis extended to distal parts of proximal tubules and epithelial cells dissociation with cast formation, lose of brush border in large parts of proximal tubules and tubular obstruction. In groups of saffron 40 and 80 $\mathrm{mg} / \mathrm{k} / \mathrm{d}$ treated rats there was no sign of histological changes or cellular necrosis, whereas both saffron 40 and $80 \mathrm{mg} / \mathrm{k} / \mathrm{d}$ reduced gentamicin induced tissue injury $(\mathrm{p}<0.05$ and $\mathrm{p}<0.01$ respectively, Table 1$)$. In the $\mathrm{S} 40+\mathrm{G} 80$ treated group necrosis and epithelial cell damage were restricted to groups of tubular cells in proximal parts of

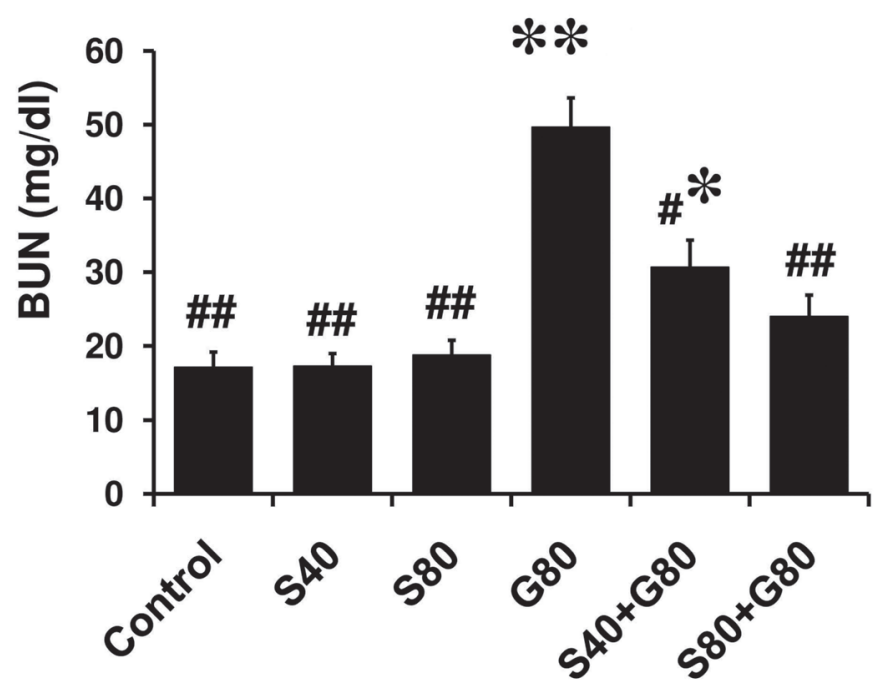

Figure 2: effect of different doses of saffron and gentamicin treatment on serum BUN Data are expressed as Mean \pm S.E.M for groups of 8 rats each. S40: Saffron $40 \mathrm{mg} / \mathrm{k} / \mathrm{d}, \mathrm{S} 80$ : Saffron $80 \mathrm{mg} / \mathrm{k} / \mathrm{d}, \mathrm{G} 80$ : Gentamicin $80 \mathrm{mg} / \mathrm{k} / \mathrm{d}$. ${ }^{*} \mathrm{p}<0.05$ in comparison to the control group, ** $\mathrm{p}<0.001$ in comparison to the control group. \# $\mathrm{p}<0.01$ in comparison to the G80 treated group, \#\# $\mathrm{p}<0.001$ in comparison to the G80 treated group (One-way ANOVA followed by Post Hoc Tukey test). 
convoluted tubules $(\mathrm{p}<0.01$ vs. control group) and in $\mathrm{S} 80+\mathrm{G} 80$ treated rats, damage was seen only in individual cells in proximal tubules with preservation of epithelial cells brush borders $(\mathrm{p}<0.05$ vs. control group).

\section{DISCUSSION}

In our study, administration of gentamicin $80 \mathrm{mg} / \mathrm{k} / \mathrm{d}$ for five days induced acute renal failure shown by functional and histological evidence. Moreover, gentamicin increased the level of renal tissue MDA production, which suggested involvement of free radicals in gentamicin-induced nephrotoxicity. Our study showed for the first time that saffron extract can reduce gentamicin-induced nephrotoxicity and preserve renal function and histology, and this effect was dose-dependent and associated with inhibition of gentamicin increased tissue MDA levels.

Drug-induced nephrotoxicity is an important cause of renal failure (Perazella, 2003). Aminoglycosides throughout the endocytic pathway are taken up into the epithelial cells of the renal proximal tubules and stay there for a long time, which leads to nephrotoxicity. Acidic phospholipids, broadly distributed in the plasma membranes in various tissues, were considered to be the binding site of aminoglycosides in brush-border membrane of proximal tubular cells (Nagai and Takano, 2004; Nagai, 2006). In accordance, the present study showed a moderate to severe histological profile in gentamicin treated group with lost brush borders in apical parts of tubular epithelial cells that was dominant in large part of proximal tubules (Table 1).

It had been shown that gentamicin treatment causes enhanced generation of superoxide anion and hydrogen peroxide (Baliga et al., 1999; Walker et al., 1999) and accelerates lipid peroxidation in the renal cortex as reflected by increased MDA, an end product of lipid peroxidation, and by depression of poly unsaturated fatty acid (PUFA), which serve as substrates for free radical attack (Holub, 1987; Chance et al., 1979). Gentamicin has been shown to lead to release of iron from renal cortical mitochondria and to enhance generation of hydroxyl radical. These in vitro observations have been supported by in

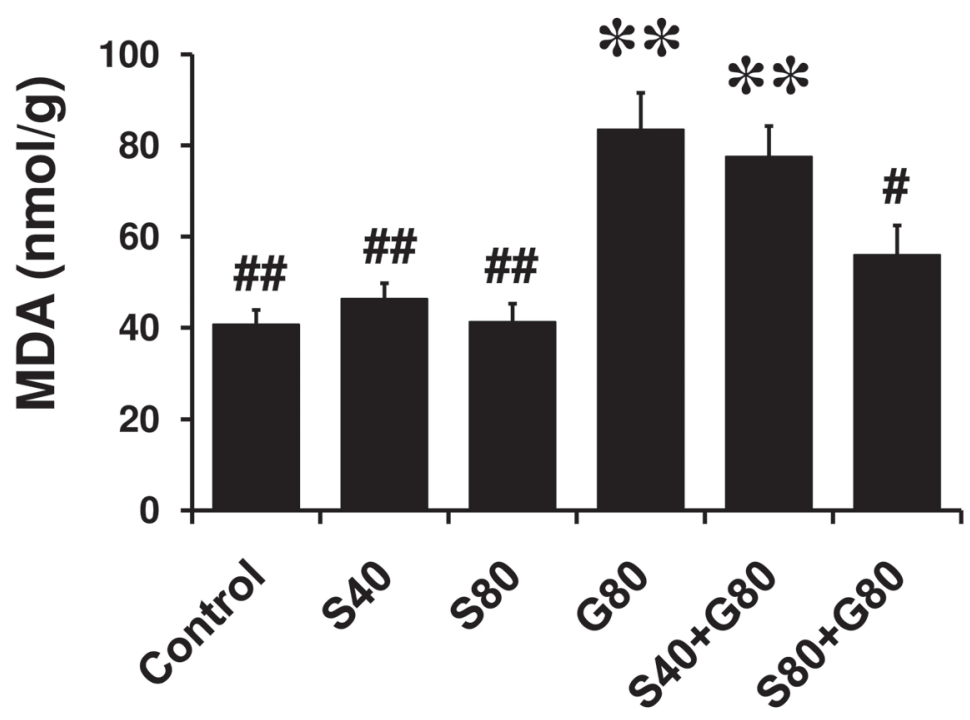

Figure 3: effect of aqueous saffron extract on lipid peroxidation in gentamicin treated rats MDA levels were measured in $10 \%$ homogenates of kidney samples. Values are mean \pm SEM $(\mathrm{n}=8)$. S40: Saffron $40 \mathrm{mg} / \mathrm{k} / \mathrm{d}$, S80: Saffron $80 \mathrm{mg} / \mathrm{k} / \mathrm{d}$, G80: Gentamicin $80 \mathrm{mg} / \mathrm{k} / \mathrm{d}$. ** p<0.001 as compared to the control group, \# $\mathrm{p}<0.05$ and \#\# $\mathrm{p}<0.01$ as compared to the G80 treated group (Oneway ANOVA followed by Post Hoc Tukey test) 
vivo studies in which scavengers of reactive oxygen metabolites and iron chelators have shown to be protective in gentamicin induced acute renal failure (MartínezSalgado et al., 2002). In the present work, along with gentamicin induced renal functional and histological impairments, there was a concomitant increase in tissue MDA levels that was in agreement with other studies (Holub, 1987; Chance et al., 1979). This confirms the role of ROS and lipid peroxidation in gentamicin induced nephrotoxicity.

In a study designed to approximate a structure-activity relationship, two bioactive constituents of saffron extract were tested, namely crocin and safranal. Crocin showed high free radical scavenging activity, followed by safranal. This free radical scavenging activity may derive from the ability to donate a hydrogen atom to free radicals (Assimopoulou et al., 2005). Purified crocin with purity of $>99.6 \%$ has an antioxidative activity at concentrations up to $40 \mathrm{ppm}$. At $20 \mathrm{ppm}$ the antioxidative activity of crocin is comparable to that of butylated hydroxyanisole (BHA; an antioxidant is used in cosmetics, drugs and foods that have unsaturated fatty acids in their structures) (Pham et al., 2000). In laying hens following 6 weeks of feeding with saffron, the rate of lipid oxidation was determined in refrigerated stored shell eggs and revealed that MDA levels in saffron diet groups was less than control group (Botsoglou et al., 2005). In our study pretreatment with saffron $80 \mathrm{mg} / \mathrm{k} / \mathrm{d}$ for five days followed by co-treatment with gentamicin $80 \mathrm{mg} / \mathrm{k} / \mathrm{d}$, reduced gentamicin induced high tissue MDA levels (Figure 3).

Related to saffron antioxidant properties in different experimental evaluations, it has been shown that pretreatment with crocin markedly inhibits oxidizing reactions after global cerebral ischemia (Zheng et al., 2007) and in hippocampal tissue after ischemia (Hosseinzadeh and Sadeghnia, 2005). In addition, pretreatment with crocus sativus $(100 \mathrm{mg} / \mathrm{k} / \mathrm{d}) 7$ days before the induction of cerebral ischemia increased the contents of glutathione (GSH) and its dependent enzymes, while preventing elevation of MDA, glutamate and aspartate contents. All this correlates well with histopathology by decreasing neuronal cell death (Saleem et al., 2006). Crocin pretreatment also reduces lipid peroxidation products, including MDA, and increases antioxidant capacity in renal ischemiareperfusion (Hosseinzadeh et al., 2005).The results obtained in the present investigation suggest that saffron extract has an overall protective effect against gentamicininduced nephrotoxicity. The observed protective effects might be attributed to the decreased levels of MDA that correlated with histological and functional data.

TABLE 1

Effects of different doses of saffron on gentamicin - induced nephrotoxicity in rats

\begin{tabular}{|c|c|c|c|c|c|c|}
\hline \multirow[t]{2}{*}{ Group } & \multirow[t]{2}{*}{ Treatment } & \multicolumn{5}{|c|}{ Number of each grade observed in each group } \\
\hline & & $0+$ & $1+$ & $2+$ & $3+$ & $4+$ \\
\hline 1 & Control \#\#\# & 8 & - & - & - & - \\
\hline 2 & $\mathbf{G 8 0} * * *$ & - & 1 & 4 & 3 & - \\
\hline 3 & S40 \#\#\# & 8 & - & - & - & - \\
\hline 4 & S80 \#\#\# & 7 & 1 & - & - & - \\
\hline 5 & $\mathbf{S 4 0 + G 8 0} * * \#$ & 1 & 3 & 4 & - & - \\
\hline 6 & S80+G80 * \#\# & 2 & 4 & 2 & - & - \\
\hline
\end{tabular}

Number of each grade observation kidneys prepared from each groups rats after treatment was shown in columns (n=8). S40: Saffron $40 \mathrm{mg} / \mathrm{kg}$, S80: Saffron $80 \mathrm{mg} / \mathrm{kg}$, G80: Gentamicin $80 \mathrm{mg} / \mathrm{kg}$.

$* \mathrm{p}<0.05, * * \mathrm{p}<0.01$ and $* * * \mathrm{p}<0.001$ in comparison with control group (Mann-Whitney Test)

$\# \mathrm{p}<0.05$, \#\# $\mathrm{p}<0.01$ and \#\#\# $\mathrm{p}<0.001$ in comparison with G80 treated group (Mann-Whitney Test). 
As shown in Figure 3, the effects of saffron in reducing of MDA levels as an indicator of lipid peroxidation of renal tissue was dose dependent. Saffron $40 \mathrm{mg}$ / $\mathrm{k} / \mathrm{d}$ did not change MDA levels. This finding confirms previous studies that showed a dose dependent effect for saffron on reducing MDA level (Abdullaev Jafarova et al., 2002; Botsoglou et al., 2005), where it has been demonstrated that the inhibitory effects of saffron against different malignant cells also was dose dependent (Abdullaev Jafarova et al., 2002). Saffron pretreatment for five consecutive days prior to the administration of anti-tumor drugs, including cisplatin, significantly inhibited anti-tumor drug induced cellular DNA damage (Premkumar et al., 2006). These findings, together with other previous results, suggest a potential role for saffron as an anti-genotoxic, antioxidant (Abdullaev Jafarova et al., 2002) and chemopreventive agent (Premkumar et al., 2006). A common feature of cytotoxicity induced by cisplatin and gentamicin is induction of ROS and lipid peroxidation (Ramsammy et al., 1985; Vermeulen and Baldew, 1992; Wachowicz and Kustro-, 1992; Fauconneau et al., 1995). In the present study saffron extract inhibited lipid peroxidation and MDA production which was in agreement with findings on cisplatin (Premkumar et al., 2001; Premkumar et al., 2006).

In conclusion, the present study demonstrated a potent reno-protective effect for saffron extract against gentamicin-induced lipid peroxidation and nephrotoxicity. Saffron-gentamicin cotreatment in our study suggests a new therapeutic strategy, but the precise mechanisms involved in saffron-induced renal protection requires further studies.

\section{REFERENCES}

ABDULLAEV FJ., (1993). Biological effects of saffron. Biofactors 4, 83-86.

ABDULLAEV JAFAROVA F, CABALLERO-ORTEGA H, RIVERÓN-NEGRETE L, PEREDA-MIRANDA R, RIVERA-LUNA R, MANUEL HERNÁNDEZ J, PÉREZ-LÓPEZ I, ESPINOSA-AGUIRRE JJ., (2002). In vitro evaluation of the chemopreventive potential of saffron. Rev Invest Clin 54, 430-6,
ABE K, SUGIURA M, YMAGUCHI S, SHOYAMA Y, SAITO H., (1999). Saffron extract prevents acetaldehyde-induced inhibition of long-term potentiation in the rat dentate gyrus in vivo. Brain Res 851, 287-289.

ASSIMOPOULOU AN, SINAKOS Z, PAPAGEORGIOU VP., (2005). Radical scavenging activity of Crocus sativus L. extract and its bioactive constituents. Phytother Res 19, 997-1000.

BALIGA R, UEDA N, WALKER PD, SHAH SV. (1999). Oxidant mechanisms in toxic acute renal failure. Drug Metab Rev 31, 971-97.

BOTSOGLOU NA, FLOROU-PANERI P, NIKOLAKAKIS I, GIANNENAS I, DOTAS V, BOTSOGLOU EN, AGGELOPOULOS S., (2005). Effect of dietary saffron (Crocus sativus L.) on the oxidative stability of egg yolk. Br Poult Sci 46, 701-7.

CHANCE B, SIES H, BOVERIS A., 1979. Hydroperoxide metabolism in mammalian organs. Physiol Rev 59, 527-605.

EDSON RS, TERRELL CL., (1999). The aminoglycosides. Mayo Clin Proc 74, 519-28.

ESCRIBANO J, ALONSO GL, COCA-PRADOS M, FERNANDEZ JA., (1996). Crocin, safranal and picrocrocin from saffron (Crocus sativus L.) inhibit the growth of human cancer cells in vitro. Cancer Lett 100, 23-30.

FAUCONNEAU B, TALLINEAU C, HUGUET F, PIRIOU A., (1995). Gentamicin-induced kidney damage and lipid peroxidation in rats. Toxicol Lett 76, 127-34.

FERNÁNDEZ J, PÉREZ-ÁLVAREZ JA, FERNÁNDEZLÓPEZ JA., (1997). Thiobarbituric acid test for monitoring lipid oxidation in meat. Food Chem 99, 345-353.

HOLUB BJ., (1987). The cellular forms and functions of the inositol phospholipids and their metabolic derivatives. Nutr Rev 45, 65-71.

HOSSEINZADEH H, KHOSRAVAN V., (2002). Anticonvulsant effects of aqueous and ethanolic extracts of Crocus sativus L. stigmas in mice. Arch Irn Med 5, 44-47.

HOSSEINZADEH H, SADEGHNIA HR, ZIAEE T, DANAEE A., (2005a). Protective effect of aqueous saffron extract (Crocus sativus L.) and crocin, its active constituent, on renal ischemia-reperfusioninduced oxidative damage in rats. J Pharm Pharm Sci $8,387-93$.

HOSSEINZADEH H, SADEGHNIA HR., (2005b). Safranal, a constituent of Crocus sativus (saffron), attenuated cerebral ischemia induced oxidative damage in rat hippocampus. J Pharm Pharm Sci 8, 394-9.

HOSSEINZADEH H, YOUNESI HM., (2002). Antinociceptive and anti-inflammatory effects of Crocus sativus L. stigma and petal extracts in mice. BMC Pharmacol 15, 7 .

JABLONSKI P, HOWDEN BO, RAE DA, BIRRELL CS, MARSHALL VC, TANGE J., (1983). An experimental model for assessment of renal recovery from warm ischemia. Transplantation 35, 198-204.

KONOPSKA B, WARWAS M., (2007). Molecular aspects of aminoglycoside nephrotoxicity. Postepy Hig Med Dosw 28, 511-8.

LOZANO P, DELGADO D, GÓMEZ D, RUBIO M, IBORRA JL., (2000). A non-destructive method to determine the safranal content of saffron (Crocus sativus L.) by supercritical carbon dioxide extraction combined with high-performance liquid chromatography and gas chromatography. J Biochem Biophys methods 43, 367-378.

MARTÍNEZ-SALGADO C, ELENO $\mathrm{N}$, TAVARES P, 
RODRÍGUEZ-BARBERO A, GARCÍA-CRIADO J, BOLAÑOS JP, LÓPEZ-NOVOA JM., (2002). Involvement of reactive oxygen species on gentamicininduced mesangial cell activation. Kidney Int 62, 168292.

NAGAI J, TAKANO M., (2004). Molecular aspects of renal handling of aminoglycosides and strategies for preventing the nephrotoxicity. Drug Metab Pharmacokinet 19, 159-70.

NAGAI J., (2006). Molecular mechanisms underlying renal accumulation of aminoglycoside antibiotics and mechanism-based approach for developing nonnephrotoxic aminoglycoside therapy. Yakugaku Zasshi 126, 327-35.

NAIR SC, PANNIKAR B, PANIKKAR KR., (1991). Antitumour activity of saffron (Crocus sativus). Cancer Lett 57, 109-114.

PERAZELLA MA., (2003). Drug-induced renal failure: update on new medications and unique mechanisms of nephrotoxicity. Am J Med Sci 325, 349-62.

PHAM TQ, CORMIER F, FARNWORTH E, TONG VH, VAN CALSTEREN MR., (2000). Antioxidant properties of crocin from Gardenia jasminoides Ellis and study of the reactions of crocin with linoleic acid and crocin with oxygen. J Agric Food Chem 48, 145561.

PREMKUMAR K, ABRAHAM SK, SANTHIYA ST, GOPINATH PM, RAMESH A., (2001). Inhibition of genotoxicity by saffron (Crocus sativus L.) in mice. Drug Chem Toxicol 24, 421-8.

PREMKUMAR $\mathrm{K}$, THIRUNAVUKKARASU $\mathrm{C}$, ABRAHAM SK, SANTHIYA ST, RAMESH A., (2006). Protective effect of saffron (Crocus sativus L.) aqueous extract against genetic damage induced by anti-tumor agents in mice. Hum Exp Toxicol 25, 79-84.

RAMSAMMY L, LING KY, JOSEPOVITZ C, LEVINE R, KALOYANIDES GJ., (1985). Effect of gentamicin on lipid peroxidation in rat renal cortex. Biochem Pharmacol 34, 3895-900.
RIOS JL, RECIO MC, GINGER RM, MANZ S., (1996). An update review of saffron and its active constituents. Phytother Res 10, 189-193.

SALEEM S, AHMAD M, AHMAD AS, YOUSUF $S$, ANSARI MA, KHAN MB, ISHRAT T, ISLAM F., (2006). Effect of Saffron (Crocus sativus) on neurobehavioral and neurochemical changes in cerebral ischemia in rats. $\mathrm{J}$ Med Food 9, 246-53.

SALOMI MJ, NAIR SC, PANIKKAR KR., (1991) Inhibitory effects of Nigella sativa and saffron (Crocus sativus) on chemical carcinogenesis in mice. Nutr Cancer 16, 67-72.

TARANTILIS PA, TSOUPRAS G, POLISSIOU M., (1995). Determination of saffron (Crocus sativus L.) components in crude plant extract using highperformance liquid chromatography-UV-visible photodiode-array detection-mass spectrometry. J Chromatography 699, 107-118.

UCHIAMA M, MIAHARA M., (1978). Determination of malonaldehyde precursor in tissues by thiobarbituric acid test. Anal Biochem 86, 279-286.

VERMEULEN NP, BALDEW GS., (1992). The role of lipid peroxidation in the nephrotoxicity of cisplatin. Biochem Pharmacol 44, 1193-9.

WACHOWICZ B, KUSTRO- J., (1992). Effect of cisplatin on lipid peroxidation in pig blood platelets. Cytobios 70, 41-7.

WALKER PD, BARRI Y, SHAH SV., (1999). Oxidant mechanisms in gentamicin nephrotoxicity. Ren Fail 21, 433-42.

ZHANG Y, SHOYAMA Y, SUGIURA M, SAITO H., (1994). Effects of Crocus sativus L. on the ethanolinduced impairment of passive avoidance performances in mice. Biol Pharm Bull 17, 217-221.

ZHENG YQ, LIU JX, WANG JN, XU L., (2007). Effects of crocin on reperfusion-induced oxidative/nitrative injury to cerebral microvessels after global cerebral ischemia. Brain Res 1138, 86-94. 